\title{
PELAKSANAAN PERKAWINAN BEDA KASTA DI BANJAR DAUHWARU, KECAMATAN JEMBRANA, KABUPATEN JEMBRANA
}

\author{
Oleh : \\ I Made Dwi Herry Purnomo, Prof. Dr. I Nyoman Natajaya, M.Pd dan Drs. Ketut \\ Sudiatmaka, M.Si \\ Jurusan Pendidikan Pancasila dan Kewarganegaraan, Undiksha Singaraja \\ Email : karnaycry@yahoo.com, natajaya45@yahoo.co.id, mettasari 88@yahoo.com,
}

\begin{abstract}
ABSTRAK
Penelitian ini bertujuan untuk mengetahui (1) faktor-faktor yang menyebabkan terjadinya perkawinan beda kasta di Banjar Dauhwaru, (2) kendala-kendala apa saja yang dihadapi dalam perkawinan beda kasta di Banjar Dauhwaru, serta (3) dapat mengetahui bagaimana pelaksanaan perkawinan beda kasta di Banjar Dauhwaru. Data dalam penelitian ini dikumpulkan dengan menggunakan metode yaitu : 1) Observasi, 2) Wawancara, 3) Pencatatan Dokumen, 4) Kepustakaan. Penelitian ini dilakukan pada masyarakat Banjar Dauhwaru, Kecamatan Jembrana, Kabupaten Jembrana. Subjek penelitian ini adalah 1) Orang yang melakukan perkawinan beda kasta, 2) Lurah Dauhwaru, 3) Kepala Lingkungan, 4) Kelian Adat, 5) Tokoh masyarakat, 6) Tokoh Agama Banjar Dauhwaru.

Hasil penelitian menunjukkan bahwa : 1). Masyarakat yang melakukan perkawinan beda kasta di Banjar Dauhwaru secara umum disebabkan oleh dua faktor yaitu faktor internal yang menyangkut tentang pribadi, dan perasaan seseorang dan faktor eksternal yang dimaksud disini adalah lingkungan, dimana baik buruknya pengaruh lingkungan akan mempengaruhi karakter atau kepribadian seseorang, serta perjodohan yang dilakukan oleh kedua pihak orang tua yang menyebabkan terjadinya perkawinan beda kasta tersebut. 2). Kendala-kendala yang dihadapi pelaku perkawinan beda kasta umumnya ialah kendala restu dari orang tua, sebagaimana diketahui restu orang tua merupakan hal yang paling penting dalam suatu perkawinan dan tanpa restu tersebut suatu perkawinan tidak akan bisa dikatakan sah. 3). Pelaksanaan perkawinan beda kasta di Banjar dauhwaru mengacu pada dua jenis perkawinan yang sering dilakukan di Banjar Dauhwaru yaitu perkawinan perkawinan pepadikan/meminang dan perkawinan ngerorod. Pada dasarnya kedua pelaksanaan perkawinan ini sama saja, terbukti dilakukannya upacara-upacara seperti upacara biakaonan, patiwangi/masepuh, maprayascita, dan pekala-kalaan, namun yang membedakan ialah tahap awal perkawinan tersebut. Bila perkawinan pepadikan diawali dengan meminang atau melamar calon mempelai serta pertemuan kedua belah pihak keluarga, sedangkan perkawinan ngerorod tahap awal yang dilakukan ialah melarikan calon mempelai tanpa sepengetahuan orang tua mempelai wanita.
\end{abstract}

Kata-Kata Kunci : Perkawinan dan Kasta 


\title{
MARRIAGE OF DIFFERENT CASTE BANJAR DAUHWARU, JEMBRANA DISTRICT, REGENCY OF JEMBRANA
}

\author{
By : \\ I Made Dwi Herry Purnomo, Prof. Dr. I Nyoman Natajaya, M.Pd and Drs. Ketut \\ Sudiatmaka, M.Si \\ Pancasila and Citizenship Education Department, Undiksha Singaraja \\ Email : karnaycry@yahoo.com, natajaya45@yahoo.co.id, mettasari 88@yahoo.com,
}

\begin{abstract}
This study aimed to determine (1) the factors that lead to different caste marriages in Banjar Dauhwaru, (2) what are the constraints faced in different caste marriages in Banjar Dauhwaru, and (3) to determine how the implementation of different caste marriages in Banjar Dauhwaru. The data collected in this study using the method are: 1) observation, 2) Interview, 3) Recording of Documents, 4) Library. The research was conducted on people Dauhwaru Banjar, District Jembrana, Regency of Jembrana. Subjects of this study were 1) People who do different caste marriage, 2) Dauhwaru Ward, 3) Head of the Environment, 4) Indigenous Kelian, 5) Public figures, 6) Religious Leaders Dauhwaru Banjar.

The results showed that: 1). People who do a different caste marriages in Banjar Dauhwaru generally caused by two factors: internal factors of the person concerned, and one's feelings and external factors referred to here is the environment, where the good and bad environmental influences will affect a person's character or personality, as well as matchmaking conducted by both the parents that caused the marriage of different caste. 2). The constraints faced by different actors caste marriages generally are constraints blessing of the parents, as is known the blessing of the parents is the most important thing in a marriage and without the blessing of a marriage can not be said to be valid. 3). Implementation of different caste marriage in Banjar dauhwaru refers to two types of marriages are often performed in a question Dauhwaru ie marriages pepadikan / woo and ngerorod marriage. Basically both the implementation of the same marriage, proved to do the ceremonies such as ceremonial biakaonan, patiwangi / masepuh, maprayascita, and pekala-kalaan, but the difference is that the early stages of the marriage. When a marriage begins to woo pepadikan or apply bride as well as meeting both sides of the family, while the marriage ngerorod initial stage was run without the knowledge of the prospective bride bride's parents.
\end{abstract}

Key Words : Marriage and Caste. 


\section{PENDAHULUAN}

Perbedaan status sosial memang eksis pada semua bangsa, tetapi dimanapun di dunia tidak ada pertingkatan kasta yang begitu kakunya, seperti yang berlaku di Bali, terutama pada masa kerajaan absolut yang berlangsung berabad-abad di Bali. Keunikan Bisa dilihat lewat bagaimana orang Bali melakukan pembinaan kekerabatan secara lahir bathin. Orang Bali begitu taat untuk tetap ingat dengan asal muasal dari mana dirinya berasal. Hal inilah yang kemudian melahirkan berbagai golongan di masyarakatnya yang kini dikenal dengan kasta atau wangsa. Tatanan masyarakat berdasarkan wangsa ini begitu kuat menyelimuti aktivitas kehidupan orang Bali. Mereka tetap mempertahankan untuk melestarikan silsilah yang mereka miliki. Mereka dengan seksama dan teliti tetap menyimpan berbagai prasasti yang didalamnya berisi bagaimana silsilah sebuah keluarga Bali. Ada yang masih begitu fanatik dengan kasta namun ada juga yang bersikap biasa saja dan tidak terlalu peduli masalah kasta. Saat ini bisa dikatakan kasta di Bali terdiri dari empat bagian yaitu : Brahmana, Ksatria, Waisya, dan Sudra. Semuanya memiliki sejarah turun-temurun yang berbeda. Meski begitu, akhirnya mereka bertemu dalam siklus keturunan yang disebut Hyang Pasupati. Begitu unik dan menarik memahami kehidupan orang Bali dalam kaitan mempertahankan garis leluhurnya tersebut. Sebagian kehidupan ritual mereka juga diabdikan untuk kepentingan pemujaan terhadap leluhur mereka.

Sebutan orang berkasta untuk wangsa tertentu dapat melambangkan harga diri mereka, karena dengan sebutan itu mereka mendapat perlakuan istimewa dan kehormatan yang berlebih-lebihan, di samping merasa dibedakan dengan kelompok masyarakat lain, yang terlanjur dianggap lebih rendah. Pada jaman dahulu, kasta sangat mempengaruhi kehidupan masyarakat Hindu di Bali. Kasta di Bali mulai kental saat masa penjajahan Belanda, sehingga penjajah dapat dengan leluasa memisahkan raja dengan rakyatnya. Selama berabad-abad penduduk Bali telah diajari bahwa kasta yang tinggi harus lebih dihormati, sehingga bila kita berbicara dengan orang yang berkasta tinggi, baik lebih muda, lebih tua, atau seusia, kita harus menggunakan bahasa bali yang halus. Tetapi bila bicara dengan orang berkasta rendah, kita tidak diwajibkan menggunakan bahasa halus.

Dalam urusan pernikahan, kasta sangat sering menimbulkan pro dan kontra bahkan kadang menjadi masalah. Sama seperti pernikahan beda agama, di Bali pernikahan beda kasta juga biasanya dihindari. Walaupun jaman sudah semakin terbuka, tapi pernikahan beda kasta yang bermasalah kadang masih terjadi.

Sebenarnya Hindu tidak mengenal kasta, yang dikenal adalah warna (berdasarkan profesi) atau wangsa (berdasarkan keturunan). Dalam sistem sosial-budaya Bali, yang kita kenal adalah wangsa, yakni silsilah keluarga berdasarkan garis keturunan. Baik menurut hukum agama maupun hukum negara, tidak ada hukuman atau ganjaran bagi orang yang menikah beda kasta/wangsa. Sistem sosial dan budaya Bali menganut sistem Patrilineal. Dalam sistem patrilineal, maka hukum adat yang berlaku adalah mengikuti garis keturunan, wangsa, dan waris suami. Mungkin yang kita tahu bahwa seorang lakilaki dengan kasta bawah yang menikah dengan wanita kasta atas tidak bisa ikut kasta wanita tersebut, sedangkan jika wanita kasta bawah menikah dengan lakilaki kasta atas maka si wanita itu bisa ikut kasta laki-laki tersebut.

Ternyata secara agama tidak dijelaskan akibat dari seorang yang menikah beda kasta. Tetapi, secara sosioreligius konseksuensinya adalah si wanita harus mengikuti silsilah keluarga suami, karena si wanita sudah masuk ke dalam silsilah keluarga sang suami. Wangsa tidak menunjukkan stratifikasi sosial yang sifatnya vertikal (dalam arti ada satu Wangsa yang lebih tinggi dari Wangsa yang lain). Namun demikian, tidak dapat 
dipungkiri bahwa masih ada warga masyarakat yang memiliki pandangan bahwa ada suatu Wangsa yang dianggap lebih tinggi daripada Wangsa yang lain. Untuk merubah pandangan seperti ini memang perlu sosialisasi dan penyamaan persepsi. Oleh karena itu, lebih baik tidak diperdebatkan lagi.

Perkawinan beda kasta sudah ada sejak dulu dan beberapa keluarga yang dulunya berasal dari wangsa yang berbeda, sekarang juga bisa hidup rukun dan membina keluarga dengan baik. Dalam hal ini, yang diperlukan adalah komunikasi yang baik antara dua keluarga dari calon mempelai. Seandainya, sudah ada kesepakatan tentang tata cara pelaksanaan upacara dan sebagainya, mungkin tidak akan ada masalah.

Kabupaten Jembrana merupakan salah satu kabupaten yang ada di Provinsi Bali, yang memiliki sebuah desa yang bernama Desa Dauhwaru. Desa dauhwaru ini terdiri dari delapan banjar adat yang salah satunya adalah Banjar Dauhwaru. Masyarakat di banjar Dauhwaru bisa dikatakan sebagai masyarakat yang modern karena Desa Dauhwaru terletak di daerah perkotaan. Kehidupan masyarakat banjar Dauhwaru tidak jauh berbeda dari masyarakat di Bali pada umumnya. Di Banjar Dauhwaru terdapat masyarakat dengan berbagai kasta, tapi sebagian besar penduduk Banjar Dauhwaru berkasta Sudra.

Berbicara masalah perkawinan, masyarakat di Banjar Dauhwaru sangat jarang melakukan perkawinan beda kasta, hal itu dikarenakan masyarakat masih berpegang kuat pada tradisi leluhur yang mengharuskan keturunannya menikahin orang yang kastanya sama. Misalnya, kasta Seorang laki-laki atau perempuan yang berkasta Brahmana harus menikah dengan laki-laki atau perempuan yang juga berkasta Brahmana, begitu pula dengan masyarakat yang berkasta dibawahnya harus menikah dengan laki-laki atau perempuan yang memiliki kasta yang sama. Tetapi pada era globalisasi saat ini, tradisi itu perlahan memudar dikarenakan banyak masyarakat
Banjar Dauhwaru yang melakukan perkawinan beda kasta. Mungkin hal ini terjadi karena pengaruh zaman yang sudah modern atau bisa juga dengan alasan saling mencintai, yang kerap menjadi alasan bagi masyarakat banjar dauhwaru untuk melakukan perkawinan beda kasta. Namun dalam pernikahan beda kasta di Banjar Dauhwaru ini juga menimbulkan pro dan kontra dari beberapa pihak diantaranya orang tua yang melarang anaknya untuk melakukan perkawinan beda kasta.

Berdasarkan uraian diatas, penulis tertarik untuk melakukan penelitian di Banjar Dauhwaru untuk mengetahui faktorfaktor apakah yang menyebabkan terjadinya perkawinan beda kasta dan kendala-kendala apa saja yang dihadapi dalam perkawinan beda kasta, serta agar penulis juga mengetahui bagaimana pelaksanaan perkawinan beda kasta di Banjar Dauhwaru. Maka dari itu penulis akan membahas kasus tersebut dalam penelitian yang berjudul " Pelaksanaan Perkawinan Beda Kasta di Banjar Dauhwaru, Kecamatan Jembrana, Kabupaten Jembrana ".

\section{Metode Penelitian}

Rancangan penelitian yang digunakan dalam penelitian ini adalah rancangan penelitian deskriptif kualitatif dengan pendekatan kualitatif sebagai metode penelitian ini dengan harapan akan mendapatkan deskripsi yang jelas tentang data serta informasi yang dibutuhkan agar tetap in fact, sesuai dengan fakta yang ada, bukan rekaan semata.

Penelitian ini mengambil lokasi di Banjar Dauhwaru, Kecamatan Jembrana, Kabupaten Jembrana. Daerah ini menjadi pilihan karena daerah ini jarang terjadi kasus perkawinan beda kasta. Tetapi dengan berjalannya waktu, perkawinan beda kasta menjadi popular di kalangan masyarakat Banjar Dauhwaru.

Dalam penelitian ini subjek penelitian ditentukan berdasarkan purposive sampling yaitu cara pengambilan yang mengikuti tujuan. Ini berarti subjek yang akan dijadikan sampel didasarkan atas ciri- 
ciri atau sifat-sifat tertentu. Sehingga yang menjadi subjek dalam penelitian ini antara lain : (1) Lurah Dauhwaru, (2) Kepala Lingkungan, (3) Kelian Adat, (4) Tokoh Masyarakat Banjar Dauhwaru, (5) Tokoh agama Banjar Dauhwaru, dan (6) OrangOrang/Masyarakat Banjar Dauhwaru yang melaksanakan perkawinan beda kasta.

Teknik pengumpulan data dalam penelitian ini, diantaranya observasil, wawancara dan pencatatan dokumen dan metode kepustakaan.

Adapun analisis data yang dipergunakan dalam penelitian ini adalah deskriptif kualitatif. Data yang diperoleh dari penelitian selanjutnya dianalisis secara kualitatif yaitu hanya mengambil data yang bersifat khusus dan berkaitan dengan permasalahan yang sedang dibahas. Dengan demikian akan menghasilkan kesimpulan yang deskriptif kualitatif yaitu dengan menggambarkan kenyataankenyataan yang sebenarnya, data yang diperoleh akan disistematisasi untuk kemudian dikaji dengan logis secara induktif sehingga akan menghasilkan pemaparan yang bersifat deskriptif kualitatif.

\section{HASIL DAN PEMBAHASAN}

\section{Hasil Penelitian}

\subsection{Faktor-Faktor Penyebab Perkawinan Beda Kasta di Banjar Dauhwaru}

Berdasarkan hasil wawancara yang peneliti lakukan dengan tokoh masyarakat, kelian adat,tokoh agama,kepala lingkungan maupun orang-orang yang melakukan perkawinan beda kasta, maka diperoleh beberapa informasi mengenai faktor-faktor penyebab terjadinya perkawinan beda kasta.

Menurut penuturan salah satu informan yang bernama Ida Ayu Kade Astuti yang telah melakukan perkawinan beda kasta dengan I Kade Punarbawa, perkawinan yang telah ia lakukan diakuinya memang didasari oleh perasaan suka sama suka dan tidak ada paksaan dari pihak lain. Selain itu ia berpendapat bahwa "perkawinan beda kasta itu tidaklah salah karena semua orang itu kedudukannya sama dan tidak ada perlu di spesialkan seperti urusan kasta" . Pendapat dari Ida Ayu Kade Astuti tersebut didukung oleh pendapat salah satu tokoh masyarakat di Banjar Dauhwaru yaitu I Nengah Darna. Beliau berpendapat bahwa "Saya setuju dengan perkawinan beda kasta karena kasta itu hanya pembagian masyarakat berdasarkan fungsi saja dan seiring perkembangan zaman maka setiap orang berhak memilih pendamping hidup tanpa memandang kasta atau kedudukan ".

Namun penuturan yang berbeda dating dari seorang informan yang juga telah melakukan perkawinan beda kasta yang bernama Ni Putu Erna Agustini yang mengatakan bahwa tekanan dari pihak keluarga dan kondisi keluarga yang tidak harmonis membuatnya merasa tertekan dan tidak nyaman. Hal ini seakan membuatnya ingin mencari kebahagiaan di luar, terlebih lagi kondisi lingkungannya sangat mendukung kearah itu, dimana banyak saudaranya dan teman-temannya melakukan perkawinan beda kasta, dan setelah perkawinannya mereka hidup bahagia dan bahkan memiliki taraf kehidupan yang lebih baik. Hal inilah yang menjadi alasan sehingga ia melakukan perkawinan beda kasta mengikuti jejak saudara dan teman-temannya.

Selain informasi di atas, peneliti juga mendapat hasil wawancara dari Kadek Wiwin Indrawan salah satu orang yang melakukan perkawinan beda kasta, menyatakan bahwa ia melakukan perkawinan beda kasta karena sudah mengenal istrinya sejak duduk di bangku SMP maka dari itu tumbuh perasaan suka sama suka dan saling mengerti antara keduanya, selain itu pihak keluarga juga mendukung keputusannya melakukan perkawinan beda kasta karena orang tua kedua belah pihak sudah lama kenal dan merencanakan perjodohan untuk anakanaknya. Selain itu ada juga yang melakukan perkawinan beda kasta karena faktor ekonomi, misalnya I Gusti Ayu Kade Yuli Widayanti yang melakukan perkawinan beda kasta untuk menopang hidup 
keluarganya karena ia berasal dari keluarga yang kurang dalam faktor ekonomi.

Sedangkan menurut Lurah

Dauhwaru yaitu I.B Komang Surya Dharma, S.Sos mengatakan bahwa ada beberapa hal yang menjadi latar belakang terjadinya perkawinan beda kasta. Misalnya pengaruh zaman yang semakin modern yang membuat generasi muda saat ini cenderung acuh dan menganggap tradisi adalah hal yang kuno yang sudah tidak relevan untuk ditetapkan di zaman sekarang. Disamping itu kembali lagi pada pribadi masing-masing dimana setiap orang memiliki cara berfikir dan pendapat yang berbeda-beda termasuk dalam cara pandang mereka mengenai perkawinan beda kasta ini. Pendapat yang berbeda dating dari Kepala Lingkungan yang mengatakan bahwa anak muda selalu memiliki rasa ingin tahu yang tinggi terhadap hal-hal yang baru. Keinginan tersebut menyebabkan banyak remaja yang walaupun tahu mengenai tradisi tetapi mereka mencoba melakukan hal yang berbeda bahkan berlawanan dengan tradisi tersebut. Hal ini bisa dimaklumi bahwa sebagai generasi muda tentu tidak dapat menutupi diri pada perubahan akan tetapi bukan berarti dengan perubahan tradisi harus ditinggalkan. Akan lebih baik jika tradisi itu tetap dipertahankan namun dengan penyesuaian-penyesuaian yang bersifat dinamis.

\subsection{Kendala-Kendala Yang Dihadapi Dalam Perkawinan Beda Kasta}

Perkawinan adalah upacara pengikatan janji yang dirayakan atau dilaksanakan oleh dua orang dengan maksud meresmikan ikatan perkawinan secara norma agama, norma hukum, dan norma social. Berdasarkan hasil wawancara yang peneliti lakukan di Banjar Dauhwaru yang berkaitan dengan perkawinan beda kasta, maka peneliti mendapatkan informasi mengenai kendala-kendala yang dapat menghambat perkawinan beda kasta tersebut, yaitu :

Menurut penuturan salah satu masyarakat Banjar Dauhwaru yang telah melakukan perkawinan beda kasta yaitu
Kadek Wiwin Indrawan yang mengatakan bahwa kendala-kendala yang dihadapinya dalam melakukan perkawinan beda kasta salah satunya ialah kendala di bidang ekonomi/finansial. Sebelum melakukan perkawinan ini ia sudah memikirkan secara matang-matang untuk melakukan perkawinan yang sakral tetapi apa boleh buat kondisi perekonomian keluarga menjadi kendala saat itu, namun atas dasar suka sama suka dan kedua belah pihak orang tua sudah menyetujui akhirnya perkawinan itu terlaksana walaupun cuma setengahnya saja.

Berbeda dengan penuturan salah satu informan yang mengatakan bahwa kendala dalam perkawinan beda kasta yang ia lakukan adalah tidak direstui oleh masing-masing pihak orang tua. Namun dengan keyakinan dan rasa cinta yang dalam terhadap pasangannya akhirnya perlahan-lahan hati kedua orang tua merekapun luluh dan merestui perkawinan anak-anaknya.

Sedangkan tokoh Agama Banjar Dauhwaru Ketut Suarma mengatakan bahwa kendala-kendala yang sering dihadapi dalam perkawinan beda kasta ini ialah kendala dari orang tua. Biasanya orang tua sangat fanatic dengan kasta sehingga mereka melarang anak-anaknya berhubungan dengan seseorang yang kastanya lebih rendah dari kasta mereka. Selain itu pekerjaan juga menjadi suatu kendala dimana bila si lelaki belum mendapat pekerjaan yang layak menurut pandangan orang tua si wanita maka pernikahan tersebut tidak akan direstui dan malah orang tua akan memaksa anaknya untuk memutuskan hubungan dengan lelaki tersebut. Dan yang terakhir yang menjadi kendala dalam perkawinan ini adalah kendala di bidang ekonomi. Banyak orang yang ingin melakukan perkawinan tetapi keinginannya itu tertunda gara-gara tidak memiliki cukup dana untuk melangsungkan upacara perkawinan dan jalan satu-satunya adalah menunda perkawinan tersebut.

Penuturan dari tokoh agama tersebut didukung oleh penuturan informan yang bernama I Putu Ngurah Ardika yang 
telah melakukan perkawinan beda kasta menyatakan bahwa sebelum menikah ia sempat tidak direstui oleh orang tua si wanita karena ia belum mempunyai pekerjaan tetap. Namun setelah menunggu selama dua tahun dan mendapat pekerjaan yang layak akhirnya ia pun direstui oleh orang tua si wanita.

Dengan mengacu pada hasil wawancara yang peneliti dapatkan maka peneliti menyimpulkan sebagai berikut :

Kendala-kendala yang dihadapi dalam perkawinan beda kasta sangat beragam, misalnya kendala di bidang ekonomi atau finansial. Kendala ini memang paling banyak kita temukan di dalam masyarakat,. Kendala seperti ini tidak hanya dihadapi oleh perkawinan beda kasta, namun perkawinan sesama kastapun mengalami kendala ini. Banyak pemuda dan pemudi yang telah siap melaksanakan perkawinan (secara mental dan bathin) tapi terkendala dari segi finansial, karena memang biaya perkawinan itu tidak lah murah apa lagi untuk daerah tertentu misalnya yang sangat kuat peran adatnya. Dimana biaya pernikahan tersebut bukan hanya mas kawin tetapi juga perlengkapan upacara lainnya. Jadi kendala ekonomi ini sangat berpengaruh terhadap jadi atau tidaknya suatu perkawinan itu.

Selain itu restu orang tua juga sangat berpengaruh dalam terjadinya suatu perkawinan,tanpa adanya restu dari orang tua maka perkawinan tidak bisa dilaksanakan dan itu akan menjadi suatu kendala dalam perkawinan tersebut. Dalam kasus perkawinan beda kasta ini biasanya orang tua masih fanatic dengan yang namanya kasta, maka dari itu jika anakanak mereka akan melakukan perkawinan haruslah dengan kasta yang sepadan atau lebih tinggi dari kastanya sendiri. Selain itu ditinjau dari UU Perkawinan dalam pasal 6 disebutkan bahwa "perkawinan harus ada persetujuan dari kedua calon mempelai dan mendapat ijin kedua orang tua ". Jadi bila suatu perkawinan tersebut dilakukan tanpa ijin atau restu dari orang tua maka perkawinan tersebut dianggap tidak sah dan seseorang yang melakukan perkawinan tersebut hidupnya tidak akan bahagia.

Selain kendala ekonomi atau finansial dan juga restu orang tua, ada juga kendala lain yang bisa di saring dari hasil wawancara yang peneliti lakukan. Kendala itu ialah belum mendapat pekerjaan yang layak. Pekerjaan merupakan salah satu factor yang menjadi kendala dalam suatu perkawinan, dimana seseorang tanpa memiliki pekerjaan yang tetap akan diragukan dalam melaksanakan perkawinan. Hal itu dikarenakan, setelah menikah orang tersebut akan mempunyai keluarga baru dan bertanggung jawab dalam menghidupi keluarganya itu. Bila belum mempunyai suatu pekerjaan maka orang itu akan diragukan dalam membentuk keluarga yang baik dan bahagia setelah menikah. Maka hal tersebut menjadi suatu pertimbangan bagi setiap orang sebelum melakukan perkawinan.

\subsection{Pelaksanaan Perkawinan Beda Kasta Di Banjar Dauhwaru}

Berdasarkan awig-awig Banjar Adat Dauhwaru yang berlandaskan Pancasila, Undang-Undang Dasar dan Tri Hita Karana, mengenai tata cara upacara perkawinan, pada dasarnya tidak jauh berbeda dengan pelaksanaan perkawinan di banjar atau desa lain khususnya yang ada di Kabupaten Jembrana. Hal ini disebabkan yang menjadi dasar atau pedoman pelaksanaan perkawinan di Banjar Dauhwaru tidak lepas dari Undang-Undang No.1 tahun 1974.

Dalam awig-awig Banjar Dauhwaru disebutkan bahwa perkawinan adalah penyatuan seorang pria dan seorang wanita yang didasari atas satu perasaan suka sama suka dan disaksikan serta disahkan dengan upasaksi baik sekala maupun niskala. Adapun syarat-syarat yang harus dipenuhi jika ingin melakukan suatu perkawinan antara lain :

a. Sudah beranjak dewasa yang ditandai dengan mampu melaksanakan dan mengikuti berbagai peraturan yang terdapat dalam Undang-Undang Perkawinan. 
b. Didasari oleh perasaan suka sama suka ( tanpa paksaan ).

c. Sesuai dengan ajaran agama.

d. Melaksanakan upacara patiwangi atau masepuh jika melakukan perkawinan beda kasta.

Selain mengatur syarat-syarat perkawinan, dalam awig-awig tersebut juga mengatur mengenai beberapa cara melakukan perkawinan yang antara lain adalah sebagai berikut :

\section{1) Pepadikan/Peminangan}

Perkawinan ini adalah perkawinan yang sudah sering dilaksanakan di Banjar Dauhwaru dimana perkawinan ini didahului oleh beberapa tahapan berdasarkan hasil wawancara peneliti dengan Ida Bagus Putu Widana dari Griya Megati, sebagai berikut :

a. Pepadikan tahap pertama adalah pertemuan kedua pihak orang tua untuk menyatakan bahwa anaknya sudah lama menjalin hubungan percintaan, untuk itu pada pertemuan ini pihak orang tua lakilaki mengesahkan pertunangan tahap pertama dihadapan orang tua dan anak-anak mereka untuk selanjutnya dengan upacara perkawinan. Namun pertemuan ini baru tahap orang tua saja dengan sarana perlengkapan Canang Pengraos dan oleh-oleh alakadarnya untuk orang tua perempuan. Dimana pertemuan ini dilanjutkan dengan pertemuan keluarga besar kedua belah pihak baik keluarga laki-laki maupun perempuan meskipun kedua belah pihak sudah sepakat sebelumnya.

b. Pepadikan tahap kedua adalah pada hari ini keluarga besar dari pihak calon pengantin pria datang ke rumah calon pengatin wanita untuk meminang. Pada saat melamar, kadang-kadang masing-masing keluarga calon pengantin mengungkap atau memaparkan silsilah keluarga. Pada saat melamar pihak keluarga atau wakil keluarga dari calon pengantin laki-laki biasanya mempersiapkan wakil keluarga yang akan menyampaikan silsilah keluarga, jika pihak keluarga pengantin wanita menanyakan tentang silsilah keluarga calon pengantin laki-laki. Mengungkap silsilah keluarga berguna untuk menghindari adanya hubungan sedarah antara calon pengantin lakilaki dan calon pengantin wanita, sehingga apabila hal itu terjadi pernikahan tersebut dapat dicegah sebelum dilangsungkannya upacara pernikahan.

Acara memadik menggunakan upakara. Adapun upakara yang dibawa pada waktu memadik (meminang), antara lain:

a. Pejati, sebagai upakara pesaksi untuk dihaturkan di pemerajan calon pengantin perempuan

b. Canang pangraos, ditambah dengan segehan putih kuning asoroh.

c. Pagemelan (rarapan) atau saserahan.

Jenis dan jumlah saserahan ini tergantung pada kesiapan, keseriusan, dan ketulusan keluarga calon pengantin laki-laki. Seserahan dapat berupa berbagai macam kue, buah-buahan, Pakaian sembahyang (pasaluk), dan alat sembahyang. Pertemuan orang tua kedua belah pihak disertai dengan keluarga besar kedua belah pihak sebagai saksi, bahwa dalam keluarga telah ada peminangan dan dilanjutkan dengan pituah-pituah orang tua kedua belah pihak. Dengan sarana Upacara Ajuma Pejati, Canang Genten, Canang Pengraos Tuak Arak.

Meskipun kedua belah pihak keluarga besar sudah sepakat namun masih ada tahapan selanjutnya yaitu upacara pewarangan yang diselesaikan dan diputuskan oleh tetua adat di Banjar Dauhwaru.

c. Pepadikan tahap ketiga 
Pada pertemuan ini adalah pertemuan yang sudah positif antara kedua belah pihak yaitu pihak orang tua dari keluarga perempuan dan pihak orang tua laki-laki beserta keluarga sudah positif akan melakukan perkawinan yang disahkan dihadapan tetua-tetua adat dan dilanjutkan dengan upacara canang pewarangan. Selanjutnya mencari hari baik (dewasa) biasanya dilakukan oleh pihak pengantin pria, dengan cara minta petunjuk kepada seorang Sulinggih atau seseorang yang sudah biasa memberikan dewasa (nibakang padewasaan). Adapun dewasa yang diminta biasanya berurutan sesuai dengan acara-acara dalam pelaksanaan upacara perkawinan, antara lain: dewasa pangenten (pemberitahuan), dewasa mererasan (meminang/mapadik), dewasa penjemputan calon pengantin wanita dan dewasa pawiwahan.

d. Pepadikan tahap ke empat

Pada tahap ini dilangsungkan upacara pendahuluan yang fungsinya untuk menghilangkan "sebel kandel" atau penyucian lahir bathin dengan biakala atau disebut juga biakaonan. Setelah melaksanakan upacara mabiakaonan maka dilanjutkan dengan upacara patiwangi ( nyerod ) dan upacara masepuh ( naik kasta) bagi mereka yang melakukan perkawinan beda kasta.

e. Pepadikan tahap ke lima

Kemudian kedua mempelai mengkuti prosesi maprayascita oleh Panditha. Dilanjutkan dengan sumpah perkawinan, Kedua mempelai saling berhadapan muka dan kedua tangan mempelai pria menggenggam kedua tangan mempelai wanita. Kemudian dilanjutkan dengan penandatanganan surat-surat nikah oleh kedua mempelai dan saksi-saksi. Setelah surat-surat nikah selesai ditandatangani, acara selanjutnya adalah Nasehat Perkawinan yang diberikan oleh Ketua Adat, PHDI, dan Keluarga kedua mempelai. Setelah nasehat perkawinan selesai, dilanjutkan dengan doa Syukur bahwa acara pernikahan dapat terlaksana dengan baik. Dimohonkan kepada semua hadirin mengucapkan doa. Setelah itu dilanjutkan dengan pekala-kalaan atau nanjung sambuk.

\section{2) Ngerorod ( Kawin Lari )}

Perkawinan ngerorod atau kawin lari biasanya terjadi karena orang tua dari salah satu pihak tidak merestui hubungan dari anak-anak mereka. Kondisi ini disebabkan oleh banyak hal misalnya karena alasan ekonomi, kehidupan social, latar belakang keluarga dan yang sering terjadi adalah karena perbedaan kasta. Adapun prosedur dalam kawin lari itu berdasarkan awig-awig Banjar Dauhwaru yaitu apabila terjadi suatu perkawinan beda kasta maka pihak pria harus menyampaikan kepada keluarga wanita dengan menunjuk beberapa orang utusan yaitu kelian adat dan beberapa orang perwakilan dari keluarga pria.

Utusan dari pihak pria tersebut tidak langsung ke rumah pihak wanita, akan tetapi utusan tersebut menyampaikannya terlebih dahulu kepada Kepala Lingkungan atau Kelian Dinas Banjar Dauhwaru. Dalam hal ini Kelian Dinas atau Kepala Lingkungan memiliki peran dan fungsi yang sangat penting sebagai perantara sekaligus mediator dari kedua belah pihak. Setelah mendapatkan laporan bahwa ada salah satu warganya telah kawin lari, maka selanjutnya Kelian Dinas akan menemui orang tua pihak wanita dan menjelaskan kondisi yang sebenarnya bahwa putri mereka telah memilih jalannya sendiri dengan melakukan kawin lari.

Dalam hal ini akan muncul dua kemungkinan diantaranya yang pertama, pihak wanita mungkin akan menerima hal tersebut sebagai sebuah takdir yang harus diterima dengan lapang dada sehingga 
mereka mau menemui utusan dari pihak pria dan berbicara dengan cara baik-baik. Akan tetapi jika keadaan tidak memungkinkan untuk mempertemukan kedua belah pihak karena pihak wanita tidak bisa menerima hal tersebut maka untuk menghindari terjadinya sesuatu yang tidak diinginkan Kelian Dinas akan mengajak Kelian Adat beserta Pecalang untuk mengantarkan utusan tersebut menemui pihak wanita.

Setelah utusan tiba di rumah wanita, maka tugas dari seorang utusan yang pertama adalah meminta maaf kepada pihak keluarga wanita atas kondisi yang terjadi dan menyampaikan surat pernyataan beserta prosesi upacara yang akan dilaksanakan. Sebelum melaksanakan upacara biakaonan, prayascita dan pakalakalaan biasanya diawali dengan upacara Mepati Wangi (Nyurudang Wangsa) sebagai symbol bahwa mempelai wanita telah melepaskan kastanya. Inti upacara ini memiliki tujuan untuk melepaskan kasta mempelai wanita agar bisa diupacarai sebagaimana mestinya oleh keluarga mempelai pria.

Dalam suatu perkawinan tidak saja faktor, kendala dan proses pelaksanaannya saja yang menjadi pusat perhatian peneliti. Namun peneliti juga akan menguak dampak setelah orang-orang tersebut melakukan perkawinan beda kasta. Di dalam suatu perkawinan pasti ada dampak positif dan dampak negative, menurut informan yang bernama I Gusti Ayu Kade Yuli Widayanti mengatakan "bahwa dampak yang ia rasakan setelah melakukan perkawinan beda kasta ialah meningkatnya atau berubahnya status social dari kasta biasa menjadi kasta yang lebih tinggi, sehingga dengan status social yang meningkat tersebut ia semakin dihargai dan dihormati oleh masyarakat sekitar".

Pendapat tersebut di dukung oleh pendapat salah satu informan yang mengatakan setelah ia melakukan perkawinan beda kasta kehidupannya menjadi makmur dan bahagia serta ia pun disegani oleh masyarakat dan dihargai.
Kondisi keuanganpun terjamin dan tidak kesusahan seperti dulu disaat belum menikah.

Namun penuturan berbeda dating dari seorang informan yang bernama I Gusti Ayu Made Sastrawati, ia mengatakan bahwa hubungan ia dan suaminya tidak sepenuhnya direstui oleh keluarga suaminya. Hal itu dikarenakan perbedaan kasta di antara mereka dan suaminya sudah dijodohkan dengan wanita lain pilihan orang tuanya. Namun ia tetap melaksanakan perkawinan beda kasta apapun konsekuensinya. Setelah menikah banyak sekali perlakuan buruk yang ia terima dari mertua dan saudara-saudara si suami, pernah juga ia menerima caciancacian dan kata-kata kasar yang keluar dari mulut mertuanya. Namun seiring berjalannya waktu akhirnya ia bisa di terima oleh orang tua si suamin dan keluarga besarnya. Sama halnya dengan Yuni Arianti salah satu informan yang mengatakan setelah melakukan perkawinan beda kasta banyak perlakuan kasar yang ia terima dari suami maupun keluarga si suami.

Dengan mengacu pada hasil wawancara tersebut, maka secara umum dampak yang terjadi setelah seseorang melakukan perkawinan beda kasta dapat diklasifikasikan sebagai berikut :

\section{Dampak Positif}

Dampak positif dari perkawinan beda kasta yang peneliti rangkum dari hasil wawancara diatas ialah adanya peningkatan status social. Dimana status social ini sangat besar pengaruhnya dalam masyarakat,apabila status sosialnya tinggi maka orang tersebut akan di hormati di dalam masyarakat tersebut. Perubahan atau meningkatnya status social seseorang disaat seseorang tersebut melakukan perkawinan beda kasta terlihat dari pada saat orang yang berkasta tinggi menikah dengan seseorang yang berkasta lebih rendah. Misalnya seorang laki-laki yang berkasta ksatria menikah dengan seorang perempuan yang berkasta sudra, maka perempuan tersebut akan naik kasta menjadi kasta ksatria dan perempuan 
tersebut akan di panggil Jero oleh masyarakat. Selain itu dampak yang sudah lumrah dirasakan oleh banyak orang yang telah melakukan perkawinan ialah mendapat kebahagiaan lahir bathin setelah berumah tangga. Hal ini dapat dilihat dari keharmonisan dalam keluarga.

\section{Dampak Negatif}

Selain dampak positif diatas peneliti juga akan mengurai dampak negative dari perkawinan beda kasta berdasarkan hasil wawancara yang peneliti dapatkan ialah adanya perlakuan yang tidak menyenangkan dalam rumah tangga, misalnya sering mendapat katakata kasar dari suami dan keluarga si suami. Hal itu terjadi karena faktor orang tua yang tidak menyetujui atau tidak merestui hubungan anaknya sehingga terjadi ketidak cocokan antara orang tua dan mantunya. Selain itu hubungan yang kurang harmonis di dalam keluarga juga bisa mengakibatkan adanya perbuatan yang tidak menyenangkan itu bisa terjadi, misalnya kekerasan dalam rumah tangga yang dewasa ini marak terjadi di masyarakat.

Selain itu, ketidak bahagiaan dalam bidang ekonomi juga bisa menjadi dampak negative. Ekonomi lagi-lagi menjadi faktor penting dalam kehidupan, apalagi dalam urusan rumah tangga. Banyak orang yang sudah menikah mengeluhkan masalah ekonomi keluarganya yang sangat rendah. Setelah menikah bukannya ekonomi menjadi makmur malah semakin rendah tingkat ekonomi dalam keluarganya.

\section{PEMBAHASAN}

Pada dasarnya perkawinan merupakan suatu hal yang amat penting dalam kehidupan orang Bali, karena pada saat itulah seseorang dapat dianggap sebagai warga penuh dari masyarakat, dan baru sesudah itu ia memperoleh hak-hak dan kewajiban seorang warga komuniti dan warga kelompok kerabat. Untuk memberikan pengertian yang lebih jelas tentang arti dari pada perkawinan dapat ditinjau dari Undang-undang Perkawinan No. 1 tahun 1974, sebagai berikut : " Perkawinan ialah ikatan lahir bathin antara seorang pria dengan wanita sebagai suami istri dengan tujuan membentuk keluarga ( rumah tangga ) yang bahagia dan kekal berdasarkan Ketuhanan Yang Maha Esa "(Drs. Sudarsono, S.H., M.Si,2005:9).

Kondisi social masyarakat Bali lebih identik dikenal dengan adanya kasta atau pembagian masyarakat. Sehingga setiap pelaksanaan perkawinan terdapat beberapa kelompok masyarakat yang masih berpandangan mengenai persamaan kasta dan menentang adanya perkawinan beda kasta. Bila kita berbicara di Banjar Dauhwaru terkait dengan perkawinan beda kasta dari hasil penelitian yang diperoleh menjelaskan bahwa sebagian besar masyarakat di Banjar Dauhwaru tidak fanatic dengan kasta dalam pelaksanaan perkawinan.

Banyak faktor yang kerap kali menjadi alasan terjadinya perkawinan beda kasta itu. Diantaranya ada yang melatarbelakangi oleh pribadi seseorang maupun perasaan yang dimiliki oleh seseorang seperti perasaan cinta yang sering kali membutakan mata seseorang sehingga demi perasaan itu mereka rela melakukan apapun asal bisa bersama dengan orang yang dicintainya. Selain itu faktor yang tidak kalah penting dapat memicu terjadinya perkawinan beda kasta adalah faktor lingkungan. Dimana lingkungan memiliki peran yang sangat penting dalam pembentukan karakter serta kepribadian seseorang. Lingkungan yang baik akan memberi pengaruh yang positif terhadap pembentukan kepribadian dan sebaliknya lingkungan yang buruk akan memberi pengaruh negative terhadap pembentukan kepribadian seseorang. Selain itu perjodohan yang dilakukan orang tua terhadap anak-anaknya juga menjadi salah satu faktor yang menyebabkan terjadinya perkawinan beda kasta. Hal ini terjadi karena masing-masing pihak orang tua sudah mengenal sejak lama dan berteman baik. Hal tersebut menjadi landasan orang tua untuk menjodohkan 
kedua putra putri mereka dengan harapan agar terjalin hubungan yang lebih dari sekedar hubungan pertemanan diantara keluarga mereka. Menurut Lurah Dauhwaru yaitu I.B Komang Surya Dharma, S.Sos mengatakan bahwa ada beberapa hal yang menjadi latar belakang terjadinya perkawinan beda kasta. Misalnya pengaruh zaman yang semakin modern yang membuat generasi muda saat ini cenderung acuh dan menganggap tradisi adalah hal yang kuno yang sudah tidak relevan untuk ditetapkan di zaman sekarang. Berdasarkan analisis tersebut tampaknya membenarkan pendapat dari Kartini Kartono $(2006,59)$ yang menyatakan bahwa baik buruknya struktur keluarga dan masyarakat akan memberikan pengaruh baik atau buruknya pertumbuhan kepribadian anak. Dari pengaruh lingkungan inilah seseorang yang tidak bisa memfilter pengaruh tersebut akan cepat terjerumus terhadap hal-hal yang negative yang tentunya akan merugikan dirinya sendiri. Selain itu tidak dapat dipungkiri bahwa kehidupan ekonomi dapat memicu terjadinya perkawinan beda kasta. Dimana jaman seperti sekarang ini tidak ada satu orang pun yang mau hidup susah, semua ingin hidup dengan berkecukupan sehingga terkadang ada orang yang rela melepaskan kastanya hanya demi meraih materi yang sebenarnya hanya kesenangan sesaat.

Perkawinan adalah upacara pengikatan janji yang dirayakan atau dilaksanakan oleh dua orang dengan maksud meresmikan ikatan perkawinan secara norma agama, norma hukum, dan norma social. Namun tidak semua perkawinan bisa terlaksana, ada juga perkawinan yang menghadapi berbagai kendala-kendala khususnya pada perkawinan beda kasta ini. Kendalakendala yang dihadapi dalam perkawinan beda kasta sangat beragam, misalnya kendala di bidang ekonomi atau finansial. Kendala ini memang paling banyak kita temukan di dalam masyarakat,. Kendala seperti ini tidak hanya dihadapi oleh perkawinan beda kasta, namun perkawinan sesama kastapun mengalami kendala ini.
Selain itu restu orang tua juga sangat berpengaruh dalam terjadinya suatu perkawinan,tanpa adanya restu dari orang tua maka perkawinan tidak bisa dilaksanakan dan itu akan menjadi suatu kendala dalam perkawinan tersebut. Dalam kasus perkawinan beda kasta ini biasanya orang tua masih fanatic dengan yang namanya kasta, maka dari itu jika anakanak mereka akan melakukan perkawinan haruslah dengan kasta yang sepadan atau lebih tinggi dari kastanya sendiri. Selain itu ditinjau dari UU Perkawinan dalam pasal 6 disebutkan bahwa "perkawinan harus ada persetujuan dari kedua calon mempelai dan mendapat ijin kedua orang tua ".

Selain kendala-kendala dalam perkawinan beda kasta tersebut, adapun solusi untuk mengatasi kendala-kendala dalam perkawinan beda kasta, ialah menarik simpatik orang tua dengan cara meyakinkan kedua orang tua bahwa calon pendamping hidup yang dipilih oleh anaknya itu tepat dan dapat membuat dirinya bahagia, karena yang akan menjalani rumah tangga adalah dirinya dan pasangannya kelak. Jika menarik simpatik kedua orang tua tidak berhasil, maka cara yang akan ditempuh adalah melakukan kawin lari/ngerorod. Dimana kawin lari ini biasanya disebabkan karena orang tua dari salah satu pihak tidak merestui hubungan anak-anaknya. Kondisi ini tidak hanya dikarenakan perbedaan kasta tetapi juga disebabkan latar belakang keluarga calon dan kehidupan social. Dengan melakukan kawin lari ini, pihak keluarga yang tidak setuju mau tidak mau harus setuju dengan keputusan yang diambil anaknya tersebut dan menerima keputusan anaknya itu dengan lapang dada.

Pelaksanaan perkawinan beda kasta di Banjar Dauhwaru mencakup dua jenis perkawinan yaitu perkawinan pepadikan dan perkawinan ngerorod. Pada dasarnya kedua pelaksanaan perkawinan ini sama saja, terbukti dilakukannya upacara-upacara seperti upacara biakaonan, patiwangi/masepuh, maprayascita, dan pekala-kalaan, namun yang membedakan ialah tahap awal perkawinan tersebut. Bila 
perkawinan pepadikan diawali dengan meminang atau melamar calon mempelai serta pertemuan kedua belah pihak keluarga besar, sedangkan perkawinan ngerorod tahap awal yang dilakukan ialah melarikan calon mempelai tanpa sepengetahuan orang tua mempelai wanita. Dengan demikian mau tidak mau orang tua mempelai wanita harus menerima keputusan anaknya dengan lapang dada dan merestui perkawinan yang dilakukan oleh anaknya itu.

\section{PENUTUP}

\section{1. kesimpulan}

Berdasarkan hasil penelitian di atas, maka dapat ditarik beberapa kesimpulan antara lain :

(1) Adapun faktor-faktor yang menyebabkan terjadinya perkawinan beda kasta dapat ditinjau dari dua faktor yaitu faktor internal dan faktor eksternal. Faktor internal berkaitan dengan perasaan seseorang yang dipengaruhi oleh rasa cinta yang sangat berlebihan terhadap orang lain terkadang menjadikan orang tersebut rela melakukan apa saja demi bisa bersama dengan orang yang dicintainya termasuk dalam hal ini dengan melakukan perkawinan beda kasta. Sedangkan faktor eksternal yang dimaksud disini adalah faktor lingkungan.

(2) Perkawinan beda kasta tidak selamanya berjalan dengan mulus, pasti dalam melaksanakan perkawinan tersebut banyak kendala-kendala yang dihadapi oleh mereka yang melakukan perkawinan beda kasta. Kendalakendala yang dihadapi dalam melaksanakan perkawinan beda kasta ini bermacam-macam misalnya kendala di bidang ekonomi atau finansial. Kendala ini memang paling banyak kita temukan di dalam masyarakat. Banyak pemuda dan pemudi yang telah siap melaksanakan perkawinan (secara mental dan bathin) tapi terkendala dari segi finansial, karena memang biaya perkawinan itu tidak lah murah apa lagi untuk daerah tertentu misalnya yang sangat kuat peran adatnya.

(3) Pelaksanaan perkawinan beda kasta di Banjar Dauhwaru mencakup dua jenis perkawinan yaitu perkawinan pepadikan dan perkawinan ngerorod.

\section{Saran}

Berdasarkan atas kesimpulan di atas, maka peneliti dapat memberikan sumbangsih saran sebagai berikut :

1) Bagi Masyarakat Banjar Dauhwaru

Saran yang bisa penulis berikan khususnya kepada masyarakat Banjar Dauhwaru yaitu masyarakat hendaknya dapat berupaya agar perkawinan beda kasta dapat diminimalisir, karena melihat dampak yang ditimbulkan dari perkawinan tersebut bukan hanya dirasakan oleh yang melakukannya tetapi juga keluarga dan kerabatnya. Hal ini bukan berarti kita menutup diri terhadap perubahan dan perkembangan zaman akan tetapi semata-mata demi kedamaian dan keharmonisan dalam hubungan kemasyarakatan.

2) Bagi Pemerintah

Pemerintah sebagai pengambil kebijakan diharapkan dapat mengeluarkan kebijakan-kebijakan yang mampu mengakomodasi serta merangkul budaya-budaya local dan berbagai tradisi yang diwariskan oleh para leluhur yang sudah berjalan secara turun-temurun, agar tradisi tersebut tidak punah dan bisa tetap dilestarikan.

3) Bagi Masyarakat Umum

Sedangkan untuk masyarakat khususnya generasi muda, janganlah masalah kasta ini dijadikan sebagai bahan pertentangan yang dapat memicu terjadinya konflik, karena hal itu hanya akan memecah belah rasa persatuan dan kesatuan yang kita miliki. Marilah dengan keberagaman ini kita saling menghargai dan menghormati serta menjaga dan melestarikan tradisi-tradisi yang sudah diwariskan oleh para leluhur kita. 


\section{DAFTAR PUSTAKA}

Benny, I Wayan. 1978. Hukum Adat Dalam Undang-Undang Perkawinan Indonesia.

Denpasar : Universitas Udayana

Bungin, Burhan. 2006. Metodologi Penelitian Kualitatif. Jakarta: PT Raja Grafindo Persada

Kanca, Nyoman. 2010. Metode Penelitian Pengajaran Pendidikan Jasmani Dan Olahraga

Kembar Karepun, Made. 2007. Mengurai Benang Kusut Kasta. PT Empat Warna Komunikasi

Moleong. 1998. Metode Penelitian Kualitatif. Bandung : PT Remaja Rosada Karya

Nasution, S. 2003. Metode Penelitian Naturalistik Kualitatif. Bandung : Tarsito

Raka Mas, Gede. 2002. Perkawinan Yang Ideal. Paramita Surabaya

Riyanto, Yatim. 1996. Metodologi Penelitian Pendidikan. Surabaya : SIC

Sudarsono. 2005. Hukum Perkawinan Nasional. Jakarta : Rineka Cipta

Trianto. 2011. Pengantar Penelitian Pendidikan Bagi Pengembangan Profesi Pendidikan Dan Tenaga Kependidikan. Jakarta : Kencana

Wiana, Ketut. 2006. Memahami Perbedaan Catur Varna, Kasta Dan Wangsa. Paramita Surabaya

Wulansari, Dewi. 2012. Hukum Adat Indonesia Suatu Pengantar. Bandung : Rafika Aditama 